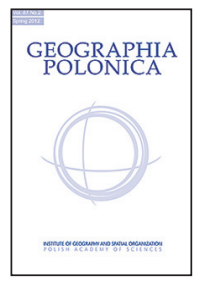

\title{
THE ODER-NEISSE LINE AS POLAND'S WESTERN BORDER: AS POSTULATED AND MADE A REALITY
}

\section{Piotr Eberhardt}

Institute of Geography and Spatial Organization

Polish Academy of Sciences

Twarda 51/55, 00-818 Warsaw: Poland

e-mail: p.ebe@twarda.pan.pl

\begin{abstract}
This article presents the historical and political conditioning leading to the establishment of the contemporary Polish-German border along the 'Oder-Neisse Line' (formed by the rivers known in Poland as the Odra and Nysa Łużycka). It is recalled how - at the moment a Polish state first came into being in the 10th century - its western border also followed a course more or less coinciding with these same two rivers. In subsequent centuries, the political limits of the Polish and German spheres of influence shifted markedly to the east. However, as a result of the drastic reverse suffered by Nazi Germany, the western border of Poland was re-set at the Oder-Neisse Line. Consideration is given to both the causes and consequences of this far-reaching geopolitical decision taken at the Potsdam Conference by the victorious Three Powers of the USSR, UK and USA.
\end{abstract}

\section{Key words}

Oder-Neisse Line - western border of Poland - Potsdam Conference • international boundaries

\section{Introduction}

At the end of the 10th century, the Western border of Poland coincided approximately with the line of the Oder (Odra) and the Lusatian Neisse (Nysa Łużycka) (Sułowski 1952). The small departures from this were of little significance, since the then political limits were somewhat labile and fuzzy. However, the era initiated by the death of Bolesław III the Wrymouthed (Bolesław Krzywousty) in 1138, which saw Poland divided up into small districts - one for each successor - brought the loss, at first periodically and then irrevocably, of the whole of Silesia and of Western Pomerania.

Thus, when the Kingdom of Poland was re-established in the 15th century, its western border was by then shifted well to the east, having an arc shape and ensuring the inclusion inside it of Eastern Pomerania, Kuyavia and Małopolska (Lesser Poland), as well as the Wielkopolska region (Greater Poland) extending further to the west (Wojciechowski 1945; 
Waszkiewicz 1954). The configuration of the border existing at this time then went more or less unmodified through to the fall of the First Republic in 1795.

The territories lost in the meantime were subject to a steady process of Germanisation, with the whole area except for some parts to the east of the Oder near Opole/Oppeln becoming ethnically German. Likewise, the Baltic coast became home to German settlement everywhere up to the mouth of the River Neman, except on the western shore of Danzig Bay. Following the fall of the First Republic, the political borderland shifted even further to the east, such that the German-Russian border ran along the River Prosna, while East Prussia ceased to be an exclave separated from Germany proper ${ }^{1}$.

In the awareness of a 19th-century Polish society partitioned into Russian, Prussian and Austro-Hungarian parts there was a wellrooted vision of Poland within its borders from 1772. This meant that Volhynia, Podolia and Lithuania were regarded as Polish lands to a greater extent than, for example, Silesia or Western Pomerania. While there was an awareness that large areas of both Silesia and East Prussia featured people using the Polish language, this was not of more major political significance. Only Wielkopolska (Greater Poland), East Pomerania and perhaps Catholic Varmia/Ermland were treated as areas to which Poland retained some moral right. Other provinces on the eastern bank of the Oder and Neisse but now in the Kingdom of Prussia were regarded as German land, and there was no fuller awareness of their early Slav origin. ${ }^{2}$

\footnotetext{
${ }^{1}$ During the previous millennium the western border of Poland did undergo a geographical shift. This was associated with the political situation in Europe, and first and foremost the position of the German Power. Nevertheless, the ultimate return was to the situation that had existed in the early Middle Ages (Labuda 1974).

2 Scant awareness of the early-Polish nature of the whole of Silesia had survived. But it had been noted by the Polish chroniclers (such as Długosz), as well as by Polish travellers spending time in Silesia in the late 18th and early 19th centuries (e.g. Niemcewicz and Plater).
}

In contrast, much was written and spoken about Polish civilisational achievements in the east, and there was no doubt in the minds of most that a whole huge area extending to the River Dnieper did represent an integral element of the Polish Lands. A similar approach was taken to the western border, which was to return to the line it followed in 1772 (Wapiński 1994).

As time passed, the highly-entrenched view in Polish society as to the territorial shape of a future Poland reborn had perforce to change radically. This did not happen under the influence of external geopolitical conditioning, which was very much petrified and did not favour Polish aspirations. Rather it was a different process that enforced a review of ways of looking at the re-creation of Poland within its historical boundaries. Across Central and Eastern Europe, peasants had remained largely indifferent to issues of nationality up to the mid-19th century, and in many cases up to the very end thereof. The carriers of tradition and identity from one generation to the next were thus the nobility and the intelligentsia. However, as time passed national ideas began to trickle down into the rural populace, along with less-subtle slogans that were nationalist in tone. This was by no means a unifying process, as the old eastern lands from the First Republic began to diverge in terms of nationality, to the extent that Ukrainian, Lithuanian, Belarusian and Latvian national movements all began to emerge.

In an analogous way (if with a more positive result) the Polish-German borderland began to nurture distinct activisms in Silesia, Pomerania, Varmia (Ermland) and Masuria, albeit with a struggle against Germanisation in each case encouraging identification with the Polish-language tradition from history (Kętrzyński 1882; Bełza 1902).

The circles formed from Polish pro-independence activists and academics (above all geographers) were thus faced with an exceptionally complex research dilemma that had consequences extending far beyond the academic. It was now necessary to square 
up to a new demographic and ethnic reality that required a rethink of many views existing hitherto, with arguments appropriate in the circumstances needing to be advanced, if the new standpoint on the extent and shape of the future Poland was to be presented properly.

\section{Precursors of Polish Western thinking}

A significant role in the development of western-orientated Polish thinking was played by the country's political activist Ludwik Popławski. He was fully aware that new political, ethnic and geographical conditions were appearing, but was less concerned about systemic and social issues (which he saw as secondary), and more interested in the key matter of assuring optimal political borders for a future Poland, in line with the fact that the fate of country and nation alike might well depend on them. He was not therefore interested in claims of a maximal nature. Indeed, he demonstrated considerable caution and wisdom, minded only by the desire to achieve cohesion and strength for the re-emerging state. It was for these reasons that he saw the issue of the western border as overriding all others.

It was clear that Poland's future would have to be linked with access to the Baltic Sea, and with the regaining of Silesia, the Wielkopolska region (Greater Poland), Pomerania and East Prussia. This view was then a precursor of the 'Piast Poland' idea ${ }^{3}$, at the heart of which was a recognition of lands in the west that were ethnically Polish. At the time, this remained a revolutionary concept. What it did not denote was any support for the so-called 'ethnic Poland', with little or no account being taken of the Eastern Lands as a whole. In fact, in the latter sphere, Popławski's views were more complex, but they certainly did not postulate a return to the historical eastern borders of the old Commonwealth. For him the sine qua non condition for Poland's existence

\footnotetext{
3 This was the first of Poland's royal dynasties reigning from the 10th to the 14th centuries.
}

was a Baltic coast extending from the Vistula to the Neman/Niemen, as well as possession of the whole of East Prussia, Greater Poland and Silesia.

Popławski stuck by his conviction that the regaining of Upper Silesia, Opole-Silesia and East Prussia was a relatively feasible option, since considerable Polish populations had persisted in all three regions. In this regard, he was aware that the postulate was maximalist in tone. Equally, he was prepared to accept that formerly Piast-ruled provinces like Lower Silesia and Western Pomerania had by now become German lands, to which Poland had permanently lost any rights or claims it might once have had. Popławski was thus consistent in not writing about any revindication in respect of areas along the middle or lower Oder, and all the more so did he eschew indicating the Oder-Neisse Line as a potential border (Popławski 1910).

Popławski's geopolitical works in fact played a key role in shaping views of the wellknown Polish politician Roman Dmowski, who saw him as an ideal instructor. In Dmowski's 1907 book Niemcy, Rosja a kwestia polska (Germany, Russia and the Polish Question), it is easy to make out the creative inspiration supplied by his great predecessor. In turn, looking from the perspective of today at Popławski's territorial concepts, it is easy to suggest that he was effective in anticipating a steady shift westwards for Poland (Dmowski 1908) ${ }^{4}$.

\section{The Russian concept of Sergei Sazonov and the Polish concept of Bolesław Jakimiak}

It can be assumed that the first justified territorial programme postulating a shift in the borders of Poland to the line of the upper and lower Oder as far as the Baltic Sea was

\footnotetext{
4 The activity of first Popławski and then Dmowski encouraged an intellectual ferment. Many activists and publicists began to consider the subject matter of Poland's western border and the situation of the Polish population made subject to planned Germanisation (Zieliński 1964).
} 
of non-Polish authorship. This reflected the fact that a major shift in the western border lay in the imperial interests of Tsarist Russia. Possibly attesting to this was the "Map of the future Europe" published in Moscow in 1914 (Alekseev 1914). It probably emerged at the inspiration of Minister of Foreign Affairs of Russia Sergei Dmitrievich Sazonov (1860-1927). On the map published there was a precise delineation of the border of the future Poland forming an integral part of Russia. Evidence of this affiliation lies in the fact that the lands of an autonomous Poland are in the same colour as the remaining Russian parts. The shape of the province dubbed 'Polska' recalls today's Poland. However, due to the scale of the map, the borders of the future Poland follow only a very generalised course. Nevertheless, along all sections they have been thought-through and are unequivocal. The western border of the planned province runs along the Oder channel from the Sudety Mountains to the Gulf of Stettin, albeit with Szczecin/Stettin itself beyond the western border. Similar annotations relating to the strongholds of Wrocław/Breslau and Głogów/ Glogau are made on the German side. The autonomous Poland has the Baltic coast from the Gulf of Stettin as far as Gdańsk/Danzig, which has been excised from the autonomous Poland and incorporated directly into Russia. Close to Gdańsk/Danzig, the border assumes a southward course and reaches Bydgoszcz/ Bromberg. The lower course of the River Vistula now belongs to Russia on both sides, with the border crossing the river close to Toruń/Thorn, whose strategic significance and location ensure its allocation to Russia. Between Torun and Osowiec, the border runs more or less west-east along the line of latitude. The whole of East Prussia together with the province of Suwałki form an integral part of Russia. The concept whereby the western border of Poland was to be the Oder has rapidly gone out of date and been forgotten.

However, real-life warfare did not proceed as an optimistic elite in Tsarist Russia had fondly imagined. Actions at the Front proved to have catastrophic consequences, and the subsequent steady erosion of the Kingdom of Poland put a stop to all of the great studies on ways in which further lands belonging to Germany might be annexed.

The first Polish visionary to propose a Polish border that not only followed the Oder but also had its southern extremity along the line of the Lusatian Neisse was Bolesław Jakimiak, who wrote under the pseudonym 'Mściwój Łohoda' (Łohoda 1918). It is hard to say if he was inspired by the Russian map. In any case, his concept was still more ambitious, since it anticipated the incorporation into the independent Poland of the whole area to the east of the Oder-Neisse line. A vision of Jakimiak's that proved a precursor was presented in a brochure published, first in Moscow and then in Warsaw in 1918. The territorial programme then proposed was far from any reality, indeed on the verge of utopian. And yet it emerged as prophetic, given that just 27 years later it had proved fully capable of being accomplished.

In his introductory chapter, Jakimiak describes the history of Poland's Western Lands, as well as the eastward political and demographical/ethnic expansion of Germany, postulating that it would only be a matter of historical justice if the whole of Pomerania, East Prussia, Nadodrze (East Brandenburg) and the whole of Lower and Upper Silesia became integral parts of the Polish state. The text offers a detailed description of each of the provinces in turn, which would await rapid repolonisation. The consequence of the establishment of the Polish-German border along the Oder and Neisse would be the automatic inclusion of East Prussia within Poland.

This reference to the western limits of Poland during the times of its first Piastdynasty rulers was in line with the historical truth. Attesting to this is a comparison between the territory of the post- 1945 Polish state and its western borders during the reign of Bolesław III the Wrymouthed (Krzywousty) in 1136.

At the time Jakimiak was formulating the border concepts cited above, the main attention of the then Polish society was turned 


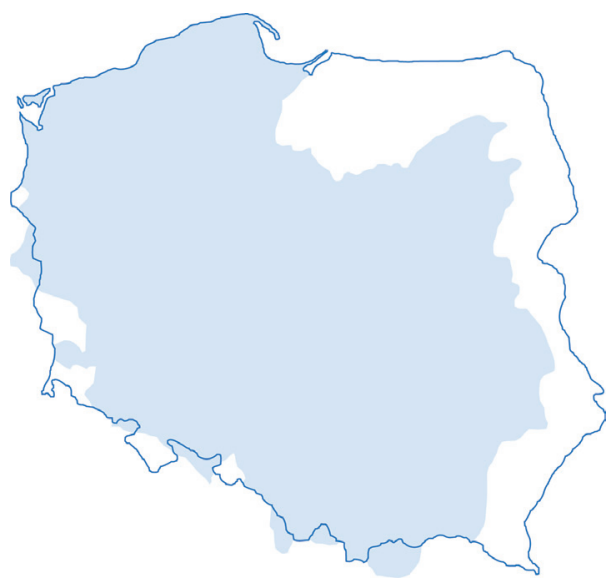

Figure 1. Boundaries of Poland as of 1136 and 1945

towards the east. It was considered that decisions as regards the western border would be taken at a peace conference in which the Western Powers would be playing a decisive role. It was also assumed that a more optimal solution than a return to the Republic's western borders of 1772 - plus limited access to the sea along with Gdańsk - would be unlikely to emerge. The bold vision postulated by Jakimiak seemed like pure fantasy in the circumstances of the political situation at the time (Kochanowski \& Kosmala 2013).

\section{The Versailles Conference}

Following the defeat in the First World War of all three of the powers partitioning Poland, the Western Powers were to determine the western limits of the reborn Republic. The Paris Peace Conference began its deliberations on 18 January 1919 at Versailles. The victorious countries called into being the Supreme Council of the Allied Powers formed from representatives of France, the United Kingdom, Italy, Japan and the United States. It was to make final determinations as regards the defeated Central Powers, this process also entailing the establishing of the future Polish-German border.

The Supreme Council in turn designated a Commission on Polish Affairs headed by French Ambassador in Berlin, Jules Cambon. Poland had to prepare its proposals as regards the borders for this Commission. In the name of the Polish Government, Roman Dmowski made a 28 February 1919 submission of a note that defined more precisely the Polish desiderata where matters such as the country's future western border were concerned (Dmowski 1947). The note in question proceeded on the assumption that the starting point for any determination of the said western border would need to be the borders as of 1772 . This condition represented an act of historical justice and was the premise behind the re-emergence of a strong state. However, that border required verification mainly to the benefit of Poland - since there were known to be areas to its west uniformly inhabited by Polish populations. Thus it was to begin running from Raciborz/Ratibor, then east of Głubczyce/Leobschutz, Prudnik/ Neustadt, Niemodlin/Falkenberg, Brzeg/ Brieg, Oleśnica/Oels and Milicz/Militsch. The whole of Upper Silesia, together with a large part of the Opole region located along the upper Odra but not belonging to the First Republic was also supposed to come within the new Poland. The Wielkopolska region (the so-called Greater Poland or once Polonia Maior) was also to be included in Poland, in this way restoring the pre-Partition border here. Dmowski also postulated the incorporation of Gdańsk/Danzig into Poland, as well as Warmia (Varmia or Ermland) and the whole southern belt of East Prussia.

The above proposals constituted a basis for the Cambon Commission's drawing up of a report on the western and southern borders of Poland. In essence, the postulates put forward by the Polish delegation gained acceptance, though they did meet with a clear protest on the part of the United Kingdom representative David Lloyd George (18631945). Indeed, his opposition did lead to certain border changes that benefited Germany (Pajewski 1963; Bierzanek \& Kukułka 1965; Karski 1998). After lengthy deliberations the Supreme Council chose 14 June 1919 to make known to the Polish delegation its verdict 
as regards the border, as well as a decision concerning the necessity of plebiscites being run. It was at a later time that the assigning of Upper Silesia took place, as well as the basic retention of the old borderline between East Prussia and the Mazowsze region (the former Masovia). ${ }^{5}$

Ultimately, the Polish-German border as agreed upon was not accepted with a great sense of satisfaction by either Poland or Germany. Extending for nearly 2000 km, it was irregular, and only reached the Oder along the section west of Rybnik. Lower Silesia, Western Pomerania and the Lubusz Land (East Brandenburg) all remained integral parts of the German State. Nevertheless, Poland had gained access to the sea, while the western border did recall in general outline the limits that had been present in 1772 .

\section{Polish western thinking in the inter-war period}

The decisions taken at Versailles simultaneously brought an end to - and gave a start to - periods of intellectual work by Polish activists and researchers as regards the future of Poland's western border and its permanence. It was seen as desirable to fix in Polish society an awareness of the need to defend against German revisionism and to ensure full integration of the new acquisitions with the remaining parts of the country. Germany was at the time engaged in anti-Polish propaganda activity that was both political and economic in character. Books published at the time sought to advance a thesis regarding the harm and hurt that had been inflicted upon Germany at Versailles, and hence the need for the Pomeranian corridor to be erased and the lands lost in the east regained.

All German centres of higher learning engaged in information-related activity concerning 'the east' (Ostforschung), ensuring the need for the Polish side to take academic counter-measures within the context

\footnotetext{
5 With the exception of the poviat of Działdowo/ Soldau, which joined Poland.
}

of a markedly offensive, rather than defensive, posture. To these ends, 1921 saw the establishment at Poznań University of a Western-Slav Institute which commenced with both academic and publishing activity. Research on geographical subject matter relating to the western lands began to be carried out then, under leading Polish geographer Stanisław Pawłowski. Toponomastic studies relating to the Polish-German borderland played a key role, with work being done to undermine hypotheses as to the German origins of these. A similar academic centre came into being in Toruń, and yet another in Katowice.

Likewise, geographers and historians in Warsaw and Krakow that had previously dealt mainly with eastern subject matter were now more and more inclined to turn their attention to the political and geopolitical consequences of the new Polish-German border (Mroczko 1986). Many books and articles appeared at this time, pointing to the existence of a potential threat posed by the neighbour to the west. There was a full awareness that the borders agreed at Versailles were of a provisional nature and might be shifted eastwards in the future (or indeed westwards). From the strategic point of view, the border that had been delineated was hard to defend.

One of the first researchers to justify the thesis that only a shift in the border to the Oder-Neisse Line would protect Poland from the German threat was Roman Umiastowski. He foresaw a future Polish-German conflict in which Poland's natural ally would be France. Furthermore, he realised that Poland's strategic goals should not be confined to defence of the status quo, but should rather be set at achieving a border that brought within Poland the area between the Sudety Mountains and the Baltic Sea, as well as extending to the Oder-Neisse Line (Umiastowski 1921).

A similar train of thought was represented by Włodzimierz Wakar, whose book written under the pseudonym 'Consulibus' referred to the armed defeat of Germany and verification of the western border. And were France 
not to accept a military solution, there would anyway be a need to eliminate East Prussia (Consulibus 1926).

Numerous works sought to attest to the geographical, historical and economic unity and homogeneity of the lands between the Oder and the Vistula. The crowning academic and popularising achievement in this respect was a convention-like gathering of historians and others running in Poznań between 6 and 8 December 1925 and called Powszechny Zjazd Historyków Polskich (the General Convention of Polish Historians). The event marked the 900th anniversary of the coronation of Bolesław I the Brave (Chrobry), but went far beyond the purely symbolic. Rather it was intended to make Polish society fully aware of its sworn duty to guard the western border, and to remember the provinces that constituted the cradle of Polish statehood (Mroczko 1986: 184). It was recalled that the lands belonging to Bolesław's Poland had included West Pomerania and the whole of Silesia. Reference was thus being made to the concept of 'Piast Poland', whose later standard-bearer would be Zygmunt Wojciechowski. A 'Jagiellonian' ${ }^{6}$ ideology was already rooted deeply in the Polish consciousness, but this was now being augmented by efforts to regenerate the 'Piast' ideology invoking Poland's return to the Oder and the Baltic Sea.

There was a degree of normalisation to Polish-German relations following the signature on 26 January 1934 (at Berlin) of the Non-Aggression Pact offering a formal guarantee that Poland would not be subject to German aggression for at least a ten-year period. This was obviously just a form of temporary camouflage which lost all significance as German power grew steadily. Following Austria's incorporation via the Anschluss and then Munich 1938 it was clear that the Versailles order had come to an end. Facing a direct threat, Poland mobilised its society and adopted a unified attitude to the military aggression that was now fully anticipated.

\footnotetext{
${ }^{6}$ Jagiellonian monarchs ruled in Poland in the 15th and 16 th centuries.
}

What was not appreciated fully, however, was the disparity in strength, and the degree to which an unavoidable political calamity was fast approaching.

\section{The concept of the Oder-Neisse border in the early phase of the war}

Following their aggressive onslaught against Poland on 1 September 1939, and the rapid takeover of western and central parts of the country, the Nazi authorities decided - by virtue of a Decree dated 8 October 1939 to incorporate 'German Pomerania' into the Reich, along with Greater Poland, Silesia, Kuyavia, northern Mazowsze, the Dabrowa Industrial District, the greater part of the voivodship of Łódź, the western poviats of the voivodships of Kielce and Krakow and the poviat of Suwatki. By further Decree (dated 12 October 1939, the German authorities established the so-called 'Generalgouvernement' (General Governorate) between the near eastern border of the Reich and a frontier established by means of the Soviet-German Pact that Molotov and von Ribbentrop had concluded on 28 September 1939.

For the Polish Government-in-Exile, operating first in France and then after the latter's capitulation in the United Kingdom, the Polish state remained constituted within the borders existing as of 31 August 1939. However, there was from early on an awareness that a return to the pre-War situation was always going to be hard to achieve, since it effectively required the simultaneous defeat of both Hitler's Germany and Stalin's USSR. Work was therefore begun to study other variants. A quite surprising initial outcome was the development of certain maximalist plans that saw the eastern border taken yet further eastwards, and the western still further to the west! It was only with Red Army victories on the Eastern Front that accommodations with the real state of affairs began, and a determination arose to defend the eastern border established following the Polish-Bolshevik War at the 
1920 Riga Conference. The assumption here was of a definitive military defeat for $\mathrm{Nazi}$ Germany, as well as victory for the Western Powers, who would then be in a position to delineate the new borders in Europe. It was further assumed that this kind of situation would allow for modification of the Polish-German border. The projects actually devised in this regard were in fact quite disparate, with rather minimalist postulates assuming nothing more than the regaining of Gdańsk and the rejoining of the divided Upper Silesia being augmented by others demanding the inclusion within Poland of the whole of eastern Germany up to the edges of Berlin and Dresden. Within the framework of these various territorial projects there was also a return of the old concept that the Polish-German border should be set by the Oder-Neisse Line (Orzechowski 1969). The approach was arrived at in both occupied Poland and in London, under the auspices of the Government-in-Exile. And from the outset, the idea began to be associated with considerations regarding future territorial vindications.

Late 1939 and early 1940 saw the establishment (still in France) of an Office of Policy Studies headed by Minister Marian Seyda. Later, in London, this took on the form of the Ministry of Preparatory Work for the Peace Conference. Its task was to work on the stance as regards Poland's future borders for the purposes of the anticipated post-War Peace Conference. At the same time, an animated discussion began back in Poland on the scope and means of implementation of Polish postulates regarding territory. The western borders in fact became the main subject of interest for the conspiratorial groups associated with the rightist movement of 'Szaniec', 'Walka' and 'Pobudka'. These prepared a number of variants, but most sought to delineate Poland's future border along a line approximating to the courses of the Oder and Neisse.

The issue of the border was also taken up at Biuro Studiów dla Ziem Nowych (the Office of Studies for the New Lands) to the Headquarters of the Union for Armed Struggle.
Its head became the known geographer Stanisław Srokowski, the former Polish Consul in Olsztyn. Commencing with its activity at the same time was the so-called 'Western Office' organised by Witold Grott, and then under the leadership of Stanisław Tabaczyński. This also began its studies on a concept for Poland's future western border. The Western Office became the Office for the Western Lands, at which the post of Director was taken up by Władysław Czajkowski. A branch of the Office was in turn the Western Section at the Department for Information and the Press of the Government Delegature founded in Poznań. It was under the leadership of Edmund Męclewski, an activist and journalist popularising knowledge on Poland's Western Lands. It cooperated with the Western Study Centre whose work was led by Zygmunt Wojciechowski.

Views expressed at the Western Office nevertheless differed. There was a minimalist approach at the outset, but later demands for Poland to even encompass the island of Rugia/ Rügen and the Lusatia region emerged. The prevailing concept was nevertheless one intending to include within Poland the whole of East Prussia, the Free City of Danzig, Szcze$\mathrm{cin} /$ Stettin in the west and all of the land to the east of the Oder and Neisse. The fact that this view was in the ascendant led its being dubbed 'Variant A' at the Western Office. All work and studies were concerned with this basic variant, though a 'Variant B' was also in fact developed, with preference for it shown by the Government-in-Exile. It assumed that the post-War western border would run along a line of longitude linking Kołobrzeg/Kolberg with Gorzów/Landsberg, and then along the Oder and Neisse down to the Czech border (Gluck 1971: 39).

There is no purpose in invoking all of the studies carried out abroad or at home in regard to possible variants for the country's future western border. Alongside collective works, there were also projects under individual authorship, and their content was influenced by political and military events in Europe, as well as the situation within the 
resistance movement, whose ideological orientations were of course diverse. In the early days it was possible to assume both a failure for Nazi Germany and the neutralisation, or even the active emasculation, of the Soviet Union. It would emerge that the latter assumption was entirely unrealistic, and had perhaps not been plausible at any stage. Indeed, a tendency to play down the USSR's political and military strength was a visible feature of all the then programmes relating to the nearer or more distant future.

The first comprehensive document to be drawn up by émigrés in Paris (of Detachment III of the Supreme Commander's Staff), and to be signed on 2 April 1940, was the Studium przyszłej granicy polsko-niemieckiej z punktu widzenia wojskowego (Study of the future Polish-German border from the military point of view), in which it was stated clearly that the optimal western border for Poland would be the line of the Oder and Neisse (Dynarski \& Derwiński 1990: 15-16).

Being aware of the degree to which their project was maximalist, the authors also worked on more limited variants, inter alia resigning from Wrocław and the whole of Lower Silesia, or else from Szczecin, In each case, they continued to stick to the stance that mastery of the whole Baltic Coast as far as the Szczecin Lagoon should be achieved. The Government-in-Exile resembled forces back home in Poland in believing unswervingly in the strength of France and in the disaster for Germany that was just a matter of time (Dynarski 1997: 87).

The radical change in the political situation arising out of the liquidation of the Western Front and Germany's complete dominance over almost the whole of Europe did rather little to limit territorial maximalism. The ultimate fall of Nazi Germany was still believed in, and the postulate regarding a border along the Oder and Neisse continued to be advanced and justified. At this stage, it is hard to assess the extent to which those persisting with this were far-sighted, and to what extent merely stubborn and dogmatic (Dynarski \& Derwiński 1990: 18).
As distinct from the prevailing view repeatedly voiced in Occupied Poland, the stance taken by the Polish Government began to undergo adjustment. This was not especially under the influence of political conditioning, but rather reflected a more precise assessment of the demographic and ethnic situation in eastern Germany, which would need to be taken within the future Poland as recompense for land lost. The calculations done by Government experts suggested that a shifting of the border to the Oder-Neisse Line would leave almost 9 million Germans within Poland. At this point there was no anticipation of a mass resettlement (eviction or expulsion) of Germans, and it was clear that their remaining within the country's borders would inevitably precipitate a crisis of Polish statehood. It was for this reason that claims on Wrocław and Szczecin were resigned from, along with those to the Baltic coast west of Kołobrzeg. In contrast, it was accepted that Poland's wish-list should include (only) East Prussia, the Gdańsk coast and Opole-Silesia/Upper Silesia. There were more precisely-defined variants within the framework of this overall concept limited in its territorial ambitions.

Not unnaturally, the views to be found among conspiratorial groups back at home were more extreme in tone and ambition. The principal advocates of border changes were activists holding nationalist views, along with many Polish academics like the geographers Jan Dylik, Maria Czekańska and Antoni Wrzosek. In fact becoming ever more firmly fixed in the minds of these people was a conviction that the Oder-Neisse Line should indeed serve as the border for post-War Poland. This view gained still-wider acceptance with time, and was thus propounded widely in the circles associated with the nationalist and peasant movements alike.

It was down to Lech Neyman, Leszek Prorok and Zygmunt Wojciechowski to develop a cohesive concept, the first of these doing so in his Szaniec Bolesławów, which begins by stating that the delineation of borders for Poland need not be driven by ethnic considerations, but should rather be conditioned 
by political and economic need, as well as the strategic situation. It was these assumptions that led Neyman to draw a future western border of Poland that is seen to run in the immediate vicinity of Berlin. There was thus a large area to the west of the Oder - and up to and including Rügen Island in the Baltic - that was intended for incorporation into Poland. In his next work Polska po wojnie (Poland after the War), the author offered a detailed presentation of his territorial intentions for Poland. In his view, the country's post-War security was dependent upon: 1) The shortest possible and most readily defensible borderline with Germany, 2) direct and extensive access to the sea, 3) a compact and cohesive area that would preclude the future emergence within the territory of enclaves of German ethnic and cultural affiliation seeking German statehood. In Neyman's view, the meeting of these three criteria would be dependent upon the establishment of a western border at the Oder-Neisse Line (Neyman 1941: 129).

It is interesting that a further postulate concerned the establishment of a sovereign Serbo-Lusation state with its capital in Budziszyn/Bautzen. At the same time, the author makes it clear that the establishment of an Oder-Neisse border would be further associated with the whole of East Prussia being irrevocably assigned to Poland (Fig. 2) (Neyman 1941: 130).

Another courageous visionary was Leszek Prorok (who went by the pseudonym 'Modrzew', meaning 'The Larch'). Prorok offered an incisive

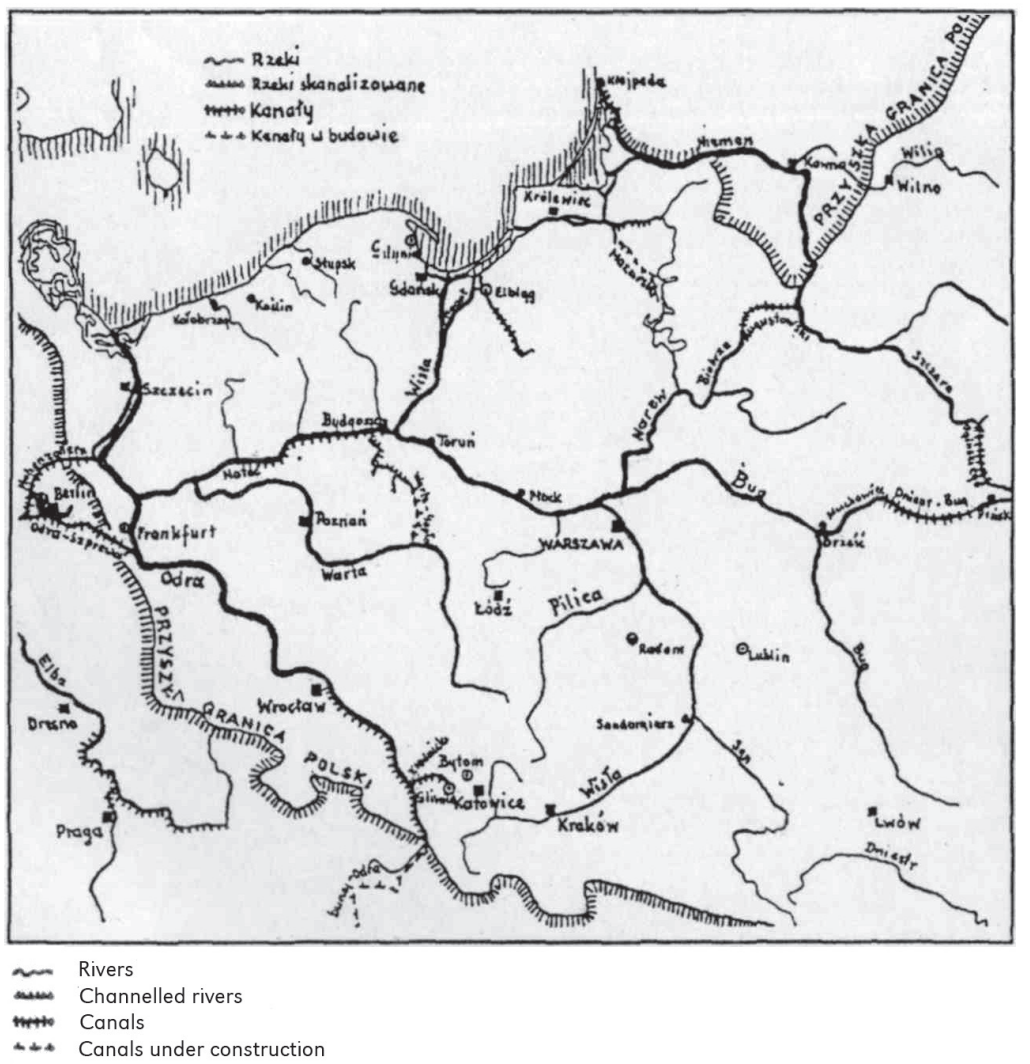

Figure 2. The future border of Poland after Lech Neyman

Source: Neyman 1941. 
and multi-stranded justification of the need for Poland to gain Germany's eastern lands up to the Oder-Neisse Line (Fig. 3). A total of 15 geopolitical, demographic, ethnic and economic/ social justifications were in fact advanced, though these can be seen to be of disparate value from the substantive point of view. While many sound rational enough, some at least are loaded with exaltation and naive optimism (Modrzew 1944: 6-7).

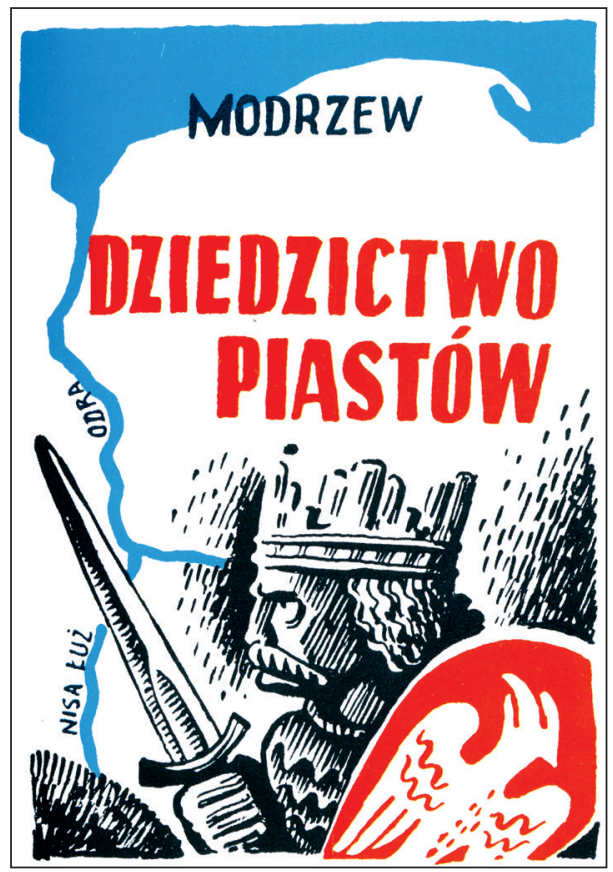

Figure 3. Heritage of the Piast dynasty (book cover picture)

Source: Modrzew 1944.

It can nevertheless be conceded that the creative activity of greatest cognitive importance was that of Zygmunt Wojciechowski, with his concept regarding the so-called 'Polish native lands' or 'Polish homelands', located in the basins of the Oder and Vistula. In the view of the author, it had been the steady loss of these to Germany that had led to political catastrophe for Poland. A major popularising role for the concept came with a book whose translated title would be Poland-Germany. Ten centuries of struggle (Wojciechowski 1945). The first of the theses that would fill the book had emerged by 1933 , but the write-up only came in 1942 , with rapid dissemination among conspiratorial groupings. Proper publication had to wait until 1945. A no-nonsense postulate presented by Wojciechowski held that "the eradication of all things German is a basic precondition for the restoration of a natural and peaceful existence in a post-War Poland". In turn, the book closed with this telling appeal, "In place of the German 'Drang nach Osten' ('Thrust towards the East'), the approaching era will be one of a renewed Slavic march to the west. He who fails to appreciate this phenomenon is not conceiving of the new era in the correct way, and does not correctly perceive Poland's place in the reality that surrounds it. As the second millennium approaches, it will again be Poland that mounts guard along the Odra" (Wojciechowski 1945: 262).

Initially, the German-Soviet war did not influence perceptions of the future (post-War) western border of Poland. No account was taken of the Soviet stance and its influence on Polish-German relations. At the outset, a victory for Hitler over the USSR was counted on, with this denoting a repeat of the geopolitical conditions present at the end of the First World War, i.e. with Poland's two major neighbours simultaneously suffering a major military reverse - to the extent that the deciding vote in a post-War Europe would be left with the Western Powers. It was only with the Battle of Kursk and the clear statement of the Soviet authorities that only the Curzon Line would suffice as an eastern border for Poland that the matter began to look less clear-cut. In such conditions, a Polish Government-in-Exile defending the idea of the Riga border in the east began to see the question of the western border in less categorical terms. It was feared the incorporation of the Eastern Lands would be facilitated if the USSR could deploy the argument regarding a so-called 'compensatory equivalent' (Kowalski \& Lippóczy 1971: 16-17). For this reason, the concept of the Oder-Neisse Line was abandoned, not only for logistical 
and ethnic reasons, but also because it might work towards Poland's loss of the Eastern Lands to the USSR.

However, the political position of the Polish Government-in-Exile weakened steadily as the War went on. To a greater and greater extent, Poland was coming to be regarded as an entity that 'had policy done to it', rather than being an active participant. What was worse, while the Three Great Powers were theoretically going to be deciding on the fate of Poland, the role of Stalin was clearly coming to dominate as time passed. In the light of this, stances taken by the Polish Government in London, and postulates advanced by the authorities of the Home Army active in Occupied Poland, both came to seem more symbolic in nature. All the more so, when it began to look as if the Soviet authorities were actually starting work on the future Polish satellite-state in at least embryonic form.

\section{The Teheran Conference}

A milestone event that brought decisions regarding Poland's new eastern border and the possibility of a degree of compensation in the west was the Conference of the Three Great Powers taking place between 28 September and 1 October 1943 in Tehran, Iran. Full documentation with stenograms of the deliberations and behind-the-scenes discussions was published long ago and there is no need to comment on the course they assumed (Zabiegło 1958; Cieślak et al. 1965). The decisions taken as regards the eastern border were unambiguous. The Soviet party obtained full approval for the delineation of Poland's eastern border along the so-called Curzon Line. There was no final determination of the future affiliations of Lvov, but it was already clear that the verdict would in the end be unfavourable for Poland. The final wording proposed by Churchill was as follows, "It was agreed in principle that the heart of the Polish state and people must be situated between the so-called Curzon Line and the line of the Oder River, including East Prussia and the Oppeln Province as part of Poland. But the final drawing of the boundary line requires thorough study and possible resettlement in some points" (Cieślak et al. 1965: 429).

Stalin's response was as follows, "The Russians have no ice-free ports on the Baltic. That is why the Russians would need the ice-free ports of Königsberg [Kaliningrad] and Memel [Klaipeda] and the corresponding part of the territory of East Prussia, particularly since these are age-old Slav lands ${ }^{7}$. If the British agree to the transfer of the said territory to us, we shall agree to the formula proposed by Churchill" (Cieślak et al. 1965: 429).

The decisions as regards Poland's eastern border were unambiguous, but the wording vis-à-vis the western border was still such as to encourage quite free interpretation. All that was known was that Poland would gain the southern part of East Prussia, as well as the province of Opole. There were, however, no indications as to how the concept of a border on the Oder was to be interpreted, since it might equally well have related to the whole of the river, or just a small stretch thereof.

Information on the decisions taken reached the Polish Government in London with some delay, since they were initially concealed. However, this was not of greater significance, since that Government was by then in a marginalised condition in any case. The loss of the Eastern Lands gained its final confirmation at the Conference in Yalta ${ }^{8}$. In contrast, settlements as regards the course of the western border were still formulated in a less-precise way, allowing for various interpretations and quite disparate decisions regarding the extent of what was to be incorporated. But

\footnotetext{
${ }^{7}$ It is hard to decide if Stalin, in referring to East Prussia as 'eternally Slavic lands', made an unintended mistake, or used it as a political argument in an awareness of Churchill's lack of knowledge of geography.

8 The Soviet side came to accept the fact that the German-Soviet Demarcation Line from the years 1939-1941 would not be restored. Furthermore, many historians do not perceive the geographical difference between the border from 28 September 1939 and that following the Curzon Line (notwithstanding the fact that that difference equates to around $23,000 \mathrm{~km}^{2}$ of territory - in Poland's favour).
} 
by this stage the future of Poland was not being decided by the Western Powers, let alone by the Government-in-Exile, but by Stalin in person. It was he who devised his own concept regarding Germany and Poland, with ever greater certainty that his Western Allies would give their seal of approval to it.

\section{Poland's western border in the assumptions of Polish communists and the government in London}

In the wake of what was agreed at Tehran, Stalin effectively had full consent to his geopolitical concepts, and might therefore proceed to the implementation of his vision for the future borders of Poland. An appropriate moment had also arrived for Polish communists in the USSR to have the plans made known to them. In line with Stalin's assumptions, these people were to be granted full authority in Poland, and that meant a necessity for agreements to be reached and consultations run. All was obviously subordinated in full to the authorities in the Kremlin, but the people in question nevertheless had a standpoint regarding what was feasible vis-à-vis the borders, and they were also fully aware of wider hopes nurtured in Polish society. What is more, they fully anticipated - and had no illusions - that their return to Poland, and their taking up of the reins of power, would see them regarded (and reviled) at home as pawns of a foreign power pursuing its policy. In fact, the groupings of Polish communists, whether active in Poland or organising under the care of the Soviet Services in Moscow, did not start off with any principled or decisive stance as regards the independence or post-War borders of their country, rather being from the outset subordinate to Soviet diktats, and hence accepting of an eastern border following the Curzon Line. A communist stance swallowing the Soviet decision regarding the eastern border without a word of objection was needless to say very unpopular in Poland and made propaganda activity more difficult. However, the struggle for the Western border was a different matter, which offered a safety valve for patriotic rhetoric to be employed without much risk, at the same time, depriving political opponents of their sole occupation of the moral high ground. Communist activists rapidly determined that the USSR was interested in a weakened Germany, and hence in Poland being compensated generously in the west. Thus, with some kind of plenipotentiary power and acceptance being present in this area at least, maximum advantage was taken. While it was nonetheless in a somewhat ad hoc way that the communists in question embarked upon their task in support of the Polish national interest, they rather rapidly found themselves adopting a strident rhetoric that had hitherto been the preserve of the Polish right.

As the Red Army came ever closer to territory that was ethnically Polish, at the same time strengthening the USSR's international position steadily, it became an ever-more topical matter to set up the new authorities, and to define more precisely what the stance as regards the western border was going to be. In line with Stalin's plan, interim authorities would come into being, not only by deploying the membership of such Moscow-based organisations as Zwiq̨zek Patriotów Polskich (the Union of Polish Patriots), but also - for the sake of appearances at least - by co-opting delegates who had remained in the Occupied Poland. Following the arrival of representatives in the so-called Krajowa Rada Narodowa (State National Council), there was - between 22 and 27 July 1944 - a session of official talks at the Kremlin. The delegation of the so-called Polski Komitet Wyzwolenia Narodowego (Polish Committee of National Liberation) was presided over by Edward Osóbka-Morawski (1909-1997), while the Soviet side was led by Stalin himself. Making only small amendments, the Polish delegates accepted the course of the Curzon Line as Poland's eastern border. The division of East Prussia into Soviet and Polish parts was also agreed upon. The east-west border was to extend from the meeting point of the borders of Poland and the Lithuanian SSR, 
taking a straight line to the north of Gołdap and Braniewo, and continuing until it reached Gdańsk Bay.

In the course of the meeting, Stalin with his own hand drew in the western border for Poland on a base map ${ }^{9}$, the result then being presented to the Polish delegates. In the west, post-War Poland would be extending as far as the Oder, and it would be along that river that the course of the border would proceed. The only distinct correction was one Stalin made - to the benefit of Poland - along the upper course of the Oder. He assigned the greater part of the Opole region to Poland and initially ran the border from the Neisse to Brzeg/Brieg. He then blurred this and shifted it between 10 and $20 \mathrm{~km}$ further to the west. Moreover, he incorporated into Czechoslovakia the Kłodzko/Glatz Basin and a small area near Raciborz/Ratibor and Głubczyce/ Leobschutz. The Polish-German border was to run along the Oder as far as the Szczecin Lagoon. In the lower part of the Oder two parallel lines were to be seen, and it may be supposed that Stalin intended this to indicate that Szczecin - to the west of the Oder - would also be included into Poland. Similarly ambiguous is the drawing of an indistinct line close to Wrocław, but on the right bank of the Oder. This allows us to wonder if Stalin at that point had a fully-formed opinion as to whom Wrocław - situated on both sides of the Oder - was to belong to.

Nevertheless, Stalin's border proposal was overall a favourable one for Poland, since it gave the country very broad access to the sea, as well as the whole of Western Pomerania, presumably also with Szczecin, as well as the Lubusz Region otherwise known as East Brandenburg. However, finding itself beyond the border of Poland was the whole of leftbank Lower Silesia. Thus a border following the line of the Lusatian Neisse was not being taken into consideration by Stalin at this time, and the whole area between what Poles and

9 Polish historian Bogdan Musiał did manage to find the map in question - hitherto unknown to researchers - at the Russian State Archives in Moscow (Musiał 2008).
Germans know as the Nysa Kłodzka/Glatzer Neisse and the Nysa Łużycka/Lausitzer Neisse was thus to remain part of Germany.

Overall, it can be presumed that the western border as drawn in by Stalin was first and foremost supposed to offer a general orientation. For at that point the leader was not fully cognisant with the views of the Western Powers, and did not know how far west the Red Army would be able to penetrate. At this time, then, his principal assumption was that the western border of Poland would indeed reach as far as the River Oder.

\section{Between the Tehran and Yalta Conferences}

The intended shift of Poland to the west was not a matter that Stalin concealed from his Western allies. Furthermore, the line of the Oder essentially won the full official acceptance of the British party. This is made clear in correspondence dated 2 November 1944 between Under Secretary-of-State at the Foreign Office Alexander Codogan and Polish Minister of Foreign Affairs Tadeusz Romer. In response to an inquiry concerning border guarantees where Poland was concerned, he responded, "(...) you enquired whether His Majesty's Government were definitely in favour of advancing the Polish frontier up to the line of the Oder, to include the port of Stettin. The answer is that His Majesty's Government do consider that Poland should have the right to extend her territory to this extent" (Rhode \& Wagner 1956: 115).

Nonetheless, in the period between the Tehran and Yalta Conferences, the Polish Government-in-Exile engaged in a determined defence of non-modification of the territorial configuration of Poland's eastern border. This was a hopeless task, doomed to failure from the outset. Churchill was quite open about the fact that he shared Stalin's point of view. Roosevelt's stance was the same, though he in fact sought to mislead representatives of the Polish authorities in the course of talks he had with them, giving them false hope that Polish wishes might nevertheless be granted, 


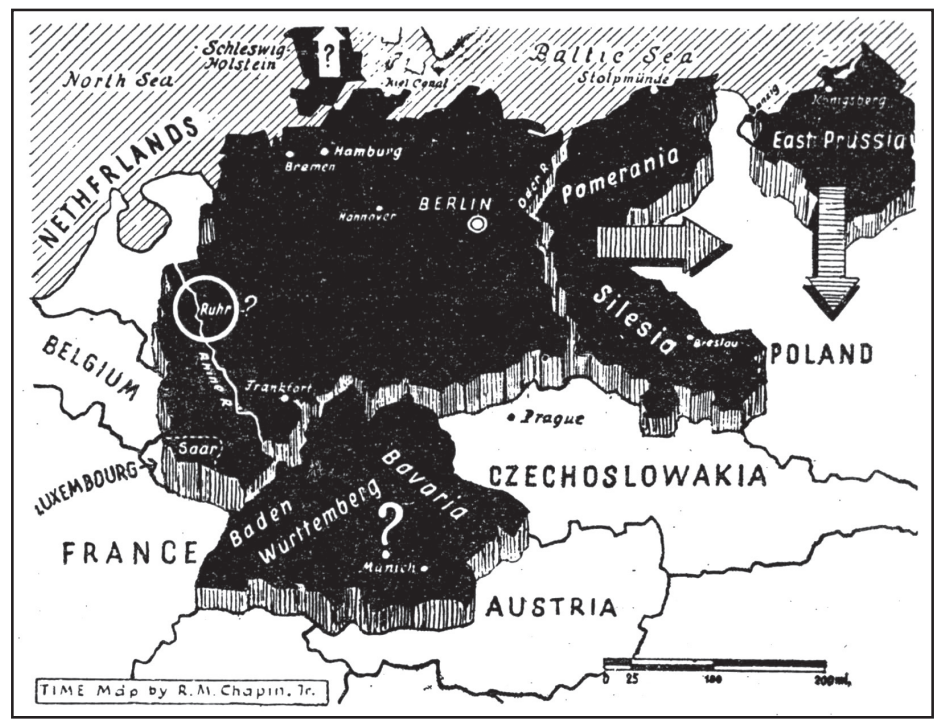

Figure 4. A plan for the division of Germany, published in the Time Magazine of 21 February 1944 Source: Kokot 1957: 96.

while at the same time disavowing this when speaking to the British and Soviets. The Polish Government's persistent struggle over the eastern border had no influence on the fait accompli decision that the Curzon Line would be followed, though it did have repercussions where the scale of the recompense that would be offered in the west was concerned. In order to undermine Polish resistance, both the Western Allies and Stalin in person were ever-more ready to reward Poland at the expense of Germany. Information on this reached both the public and the Western mass media. While particulars remained unknown, journalists were beginning to speculate in this matter. Taken as a good example here is the map published in Time on 2 February 1944, which makes clear that the 'compensation' for Poland might entail territory extending as far as the Oder-Neisse Line (Fig. 4) ${ }^{10}$.

With the exception of a few communists, Poland's political elite had a range

\footnotetext{
10 This was one of the many proposals to make an appearance in the wartime United States. Some like those of Kaufmann (1941), Welles (1949) or Morgenthau (1945) provided for the total elimination of the German state (Kokot 1957: 20-21).
}

of disparate and inconsistent views on the course of the western border that stood in contrast to the emotionally-motivated and unequivocal stance where the eastern limits of the country had been concerned. The Polish Government did not approve of the idea that extra recompense in the east might be made available. This was not merely because it was linked irrevocably with the loss of land to the east of the Cuzon Line, but also because there were fears as regards a large German minority that would severely limit the cohesion of any new Poland.

The scale of territorial gains in the west became an extremely controversial matter that divided opinion-formers both in Poland and in emigration abroad. Poland's obtainment of the whole of East Prussia, of Gdańsk/ Danzig and of the Opole region did not evoke reservations, with the result that the stance was unified in this matter. There was also an inclination to accept the granting of the whole of Pomerania, or even the whole coast up to the Szczecin Lagoon (though excluding Szczecin itself). On the other hand, the idea of a border along the Oder-Neisse Line, with the whole of the Oder mouth also included 
in Poland, had both its fervent supporters and a large number of opponents.

A minimalist stance was taken by Tadeusz Katelbach as the representative of the German Section at the Ministry of Information and Documentation of the Republic of Poland, who only wanted East Prussia, Gdańsk and Opole-Silesia. At the same time, an ever-wider political circle (not only associated with the Polish right) began to demand a border following the Oder-Neisse Line.

Polish opinions - and most especially those voiced outside the country - had ceased to have any political significance. However, what remained was the symbolic dimension, which served as testimony to the indefatigable nature of the struggle for the country's integrity. It was by then known that the decision would be taken by the three Great Powers, and in essence arbitrarily by Stalin, who would agree on it and consult with Churchill and Roosevelt.

\section{The Yalta Conference}

The next conference participated in by the leaders of the three Great Powers took place between 4 and 11 February at Yalta on the Crimean Peninsula. There is no need to discuss this here, as it is very widely known (Plokhy 2010; Kersten 2011). However, it is worth citing the verdict as regards Poland's borders that was arrived at. This read as follows, "The three Heads of Government consider that the eastern frontier of Poland should follow the Curzon Line with digressions from it in some regions of five to eight kilometres in favour of Poland. They recognize that Poland must receive substantial accessions in territory in the north and west. They feel that the opinion of the new Polish Provisional Government of National Unity should be sought in due course on the extent of these accessions, and that the final delimitation of the western frontier of Poland should thereafter await the peace conference".

The decision of the leaders of the Three Great Powers as regards the eastern and western borders of the post-War Poland differed markedly in the degree to which they were considered obligatory and unambiguous. The text formulated as regards the future Polish-German border was in fact exceptionally opaque and imprecise, offering a great deal of room for manoeuvre when it came to interpretation. A line following the Oder was not in fact mentioned, or any other more precise delineation of the border for that matter. In fact the idea of the Oder Line did arise in the course of plenary discussions, as well as in the corridors, but no precisely-defined obligations were linked with it. There was an even a proposal from Molotov that the provisions relating to Poland's borders should be augmented by an insert worded as follows: "(...) with a restoring to Poland of its old borders in East Prussia and on the Oder".

Roosevelt did not consent to this, though there was a conviction among the Western Allies that Stalin was a clear advocate of Poland's shift to the west, and that the border would reach the Oder. This could not be kept out of the public domain.

In the immediate aftermath of the Yalta Conference, Churchill told the House of Commons on 27 February 1945 that "(...) the three Powers have now agreed that Poland shall receive substantial accessions of territory both in the North and in the West. In the North she will certainly receive, in the place of a precarious Corridor, the great city of Danzig, the greater part of East Prussia west and south of Königsberg and a long, wide sea front on the Baltic. In the West she will receive the important industrial province of Upper Silesia and, in addition, such other territories to the East of the Oder as is may be decided at the place settlement to detach from Germany after the views of a broadly based Polish Government have been ascertained" (Kowalski \& Lippóczy 1971: 75).

A couple of days later, on 1 March 1945, Roosevelt addressed a Joint Sitting of Congress, declaring that "The limits of the western border [i.e. of Poland] will be permanently fixed in the final peace conference. We know roughly that it will include in the new strong Poland quite a large slice of what is now called Germany. And it was agreed also that 
the new Poland will have a large and long coastline and many a new harbor. Also that East Prussia, most of it, will go to Poland".

\section{Between the Yalta and Potsdam Conferences}

After Yalta, the future political and territorial position became ever-clearer. In line with what had been adopted, the area of postWar Poland was to extend between the Curzon Line in the east and an approximation of the Oder Line in the west. The future allegiance of Szczecin and Lower Silesia with Wrocław had not yet been determinedly. It can be assumed that Stalin was also working to achieve a transfer to Poland of areas on the left bank of the Oder, just as the Western Allies supported the idea that these lands should remain German. This was in line with the known opinion of Churchill made clear to Stalin on 7 February 1945 in the course of the 4th Plenary Sitting of the Yalta Conference, "It would be a pity to stuff the Polish goose so full of German food that it got indigestion".

It was also Churchill's intention that the size of the post-War expulsion/resettlement of the German people should be minimised, and it was in the light of this that Churchill, as supported by Roosevelt, found the establishment of a border along the Oder-Neisse Line a rather problematic solution, and one whose outcome following the anticipated surrender of Germany would be very much dependent on political conditions ${ }^{11}$.

In turn, the premises that had guided Stalin as he supported the concept of Poland's being shifted as far as possible westwards were described very effectively by Musiał (2008: 154-156) - as a Polish historian dealing with Soviet policy towards Poland and Germany. He expressed his point of view on this with words (of course in Polish) to the following effect, "A fundamental question arises

\footnotetext{
11 Much information on Churchill's position as regards Poland's borders is to be found in his multi-volume memoirs (Churchill 1950, 1954ab).
}

as to what was motivating Stalin when he opted for a delineation of the western border of Poland along that very same Oder-Neisse Line. After all, Stalin was no friend of Poland and Poles, to say the least of it. Indeed, his instincts towards the country were decidedly hostile in this respect as always. While that hatred of Poles reached its zenith with the Katyn Massacre, after 22 June 1941 Stalin also commenced with his aforementioned hatred of Germany, and Germans likewise. From that time forward, inflicting military defeat on Germany became one of the objectives of the War designated by Stalin, along with the division of that country once defeated, the destruction of its industry, and a westward 'shove' for the zone of German settlement in Europe (...). It is also impossible to ignore a further example of the clearlyexpressed will of Stalin, which is to say the circumstance that Poland's westward shift ensured decades of dependence on the Soviet Union, this being at the time (and likewise decades later) the sole guarantor of Poland's western border".

In the view of the above author, the idea of Poland being shifted to the west was voiced by Stalin for the first time in September 1941, in a conversation with Georgi Dimitrov. It was then put to General Władysław Sikorski in December 1941, in the course of his stay in Moscow. As time passed, the idea only became more precisely defined, but after the Potsdam Conference it was a geopolitical reality.

The political position of the Soviet Union was being reinforced steadily, partly thanks to the military success of the Red Army, which was rapidly advancing westwards. It was these forces that took Berlin and Vienna and reached the middle Elbe, along which the Allies met. At the same time, events of significance were taking place in eastern Germany. Fearful or the approaching Red Army, millions of Germans began to flee westwards in disorder. It is estimated that the final phase of the War coincided with the departure of some 5-6 million Germans from areas located to the east of the Oder-Neisse Line. 
Operatives of the Polish field administration began to move in at the same time, enjoying consent to do this from the Soviet military authorities. While there were frequent Polish-Soviet conflicts, the authorities of the latter went beyond mere toleration, regarding these people as the body shaping Polish administration that enjoyed full legal entitlements. A start was also made - rather spontaneously - to the resettlement/eviction of elements of the German population that had not left of their own accord, as well as the bringing in of Poles in line with the plans. Units of the Polish People's Army also began to man the Oder-Neisse Line as border, notwithstanding the lack of any international consent for this. This type of intentional action designed to indicate that things were already done deals had as its overriding aim the de-Germanisation of lands along the Oder, and their repopulation with people who were ethnically Polish. It was anticipated that this would exert an influence on the decision taken by the Three Powers, making it more likely that a verdict favourable to Poland would be arrived at. This was in fact to be the crowning argument in favour of a handover of these lands to Poland.

First preparatory work was engaged in as early as in 1944 in Lublin. The aforementioned Office for the Western Lands was established, along with the first operational groups that were to follow on behind as the Front advanced. Once the Red Army's January Offensive had begun, the Council of Ministers of the Provisional Government on 2 March 1945 called into being a Commission whose task it would be to determine the organisational principles underpinning the administration of the western and northern lands. The concept developed was for the establishment of district and county-level Government Plenipotentiaries enjoying a wide range of powers. A resolution adopted would see the Regained Lands divided into the four districts of: I - Ślask Opolski (Upper Silesia as then identified with Opole-Silesia), II - Dolny Śląsk (Lower Silesia), III - Pomorze Zachodnie (Western Pomerania) and IV - Warmia (Ermland) and Mazury (Masuria). Then established on 11 April 1945 to ensure efficient governance was a post of General Plenipotentiary for the Regained Lands, and subsequently a State Repatriation Office whose remit was to coordinate actions leading to the settlement by a Polish population of lands incorporated into Poland (Gluck 1971: 94-95).

Also involved in the undertaking was the Polish People's Army, and - by virtue of an order from its Supreme Commander dated 3 June 1945 - work began on the organisation of military settlement in the 15 poviats adjacent to the Oder and Neisse). 140 operational groups were in turn delegated for this purpose, while a further task for the army was to see to the expulsion of the remaining German populations to areas beyond the Oder-Neisse Line (Gluck 1971: 93).

The action referred to was always anticipatory in nature, since there was no legal sanctioning for it from the international community. It was known that Poland would be gaining territory in the west, but exactly how much remained uncertain at the time. The upcoming Peace Conference for the three victorious powers was the only one enjoying the right to arrive at a final decision in this matter. The Soviet authorities allowed the Polish administration to take up a wide variety of undertakings, but in doing so they were acting in their own interest. However, they were then merely proponents of lands along the Oder (including Szczecin and Wrocław being incorporated into Poland (Heitmann 2002; Debra 2003; Thun 2011).

\section{The Potsdam Conference}

In the wake of the tripartite agreement reached between the authorities of the Soviet Union, the United States and the United Kingdom, a decision was taken to hold a third meeting of the leaders of the Three Powers, i.e. Stalin, Churchill and - following the death of Roosevelt - new US President, Harry S. Truman. The victors were to determine the fate of Germany, as well as establishing 
the post-War European order where the continent's new borders were concerned ${ }^{12}$. It was determined that the venue for the meeting would be Potsdam, just outside Berlin. It was also known that the western borders of Poland would be determined at this point, and there was likewise an awareness that Stalin was positively disposed towards the process, and that it would be mainly for him that relevant documentation and arguments would need to be made ready, since he would be the one presenting these on to Churchill and Truman. The editing was to be such as to ensure ready understanding, as well as an appropriate level of synthesis, all with a view to the Western Allies being readily convinced. It was further known that Churchill's attitude would be less than fully supportive of Polish postulates. Thus teams of Polish academics, principally in Poznań and Krakow (since the Warsaw centre had been annihilated during the Uprising) worked to prepare relevant substantive arguments in line with history, geography, demography, statistics and the economy. Noteworthy among a number of proposals for the borders was an in-depth one advocating a shift to the western banks of the Lusatian Neisse and the Oder, in line with justifications of both a strategic and an economic nature. This concept was prepared by a team comprising Maria Kiełczewska, Leopold Gluck and Zdzisław Kaczmarczyk (1946). All the studies were then submitted to the communist authorities of Poland, and in this sphere at least there was found to be a common set of national interests. Thus the government's territorial programme even won the support of academics with anti-communist views.

As the Potsdam Conference deliberations began (on 17 July 1945), Bierut and Osóbka-Morawski - as respectively the President and Prime Minister of the so-called Provisional Government of National Unity - made an appeal to Stalin, Churchill and Truman for

12 Like that concerning the Tehran and Yalta Conferences, the documentation arising out of the Potsdam Conference is very extensive (RIIA 1946; USDS 1955; Butler et al. 1984; BDGG 1985). the Polish-German border to be set along the Oder-Neisse Line, with the city of Szczecin also being assigned to Poland. On the following day, Truman extended an invitation to the Polish delegation for 24 July 1945, in his own name and that of both Churchill and Stalin.

Making up the Polish delegation, alongside official representatives in the shape of Bolesław Bierut, Edward Osóbka-Morawski, Stanisław Mikołajczyk, Władysław Gomółka, Stanisław Grabski and Wincenty Rzymowski, was a group of experts comprising Andrzej Bolewski, Walery Goetel and Stanisław Leszczycki. These experts were extremely well-prepared for the role that had been assigned to them, and they had left over - from the time of the Occupation - a ready-made substantive justification for a western Polish border following the Oder-Neisse Line. There were several annexes offering a synthesis of the arguments in favour of this decision. These considered the political and moral arguments, territorial and demographic matters, historical truths regarding Poland, geographical location and geopolitical and economic linkages between the Western Lands with Poland. The work ended with the following appeal to the effect that strategic issues needed to be brought into sharp relief, "The border along the Odra and Nysa ['Nisa' in the original] and the destruction of East Prussia as a cradle of German Junkerism will eliminate a place d'armes convenient for the Germans, making it impossible for them to enjoy the most favourable and suitable conditions should they mount an attack on the Polish lands. The liquidation of East Prussia and the marked reduction in the length of the 1912 border (to about $350 \mathrm{~km}$ ) will allow for more effective defence of the frontier. A border formed by the Odra and Nysa is the natural one most conducive to effective defence. It will remove the wedge of territory existing in 1939 between Poland and Czechoslovakia, and will represent for the Soviet Union and all of the Slav lands, as much as for Poland, the best barrier to ever-possible aggression on the part of Germany" (Rysiak 1970; Bolewski 1977). 
A key substantive argument was the way it had been demonstrated that the pre-War Polish border with Germany - established at Versailles - was irrational, and was one of the causes of yet another World War. It had been thanks to the configuration of the border that the Germans had been provoked into hostile activity against Poland. These truths were set out in a couple of points justifying the 'artificial' status of the provisions from Versailles, which it was considered should not be repeated, from the point of view of the security of Europe as a whole, and not merely Poland. These entailed:

- the assigning to Poland of excessively limited access to a sea continually threatened by German aggression,

- the establishment by the mouth of the Vistula of a Free City of Danzig, whose artificial structure resulted in an artificial cutting-off of the Vistula basin from the Baltic Sea,

- the use of East Prussia as a political barrier barricading off Poland from the Baltic Sea,

- the separation of Poland and Germany by a border of excessive (1912 km) length, that was hard to defend,

- depriving Poland of its lands along the Oder that formed - together with the area of the Vistula basin - a single geographical whole aligned towards the Baltic Sea,

- depriving Poland of a great part of the natural resources of Silesia, and of Baltic ports, as well as disrupting the economic integrity of the western Polish lands (Silesia, Greater Poland and Pomerania) to the extent that resources that would have allowed for the development of industry were lacking.

According to the Polish delegation, avoidance of the mistakes that had been made in 1918 and that had resulted in the Second World War would require a Polish-German border established along the Oder-Neisse Line, as well as the liquidation of East Prussia, as a bastion of German imperialism. It was apparently the uniform opinion of the Polish nation that: "The new Poland should constitute a geopolitically homogeneous territory between the Sudety and Carpathian Mountains and the Baltic, as well as between the Odra and the Western Nysa, and the Bug and Niemen. The international political situation in Europe requires that an end should at last be put to the German wedge between Poland and Czechoslovakia, which proved a threat to peace. Poland must have a border that hinders German aggression, and that would be the line formed by the Odra and the Western Nysa, which shortens the Polish-German border. (...) Moral considerations also speak for the incorporation of areas beyond the Western Nysa and Odra into Poland. Through the whole War Poland was unwaveringly on the side of the Allies, acting in line with its strength and capabilities in the interests of the joint victory. Poland has borne the heaviest losses in both people and cultural and material goods. In the name of overall human justice, Poland is deserving of redress" (Bolewski 1977: 203-205).

The statement also offered a discussion of demographic issues, and most especially the need to make room for 4.2 million repatriated incomers from the east and 2 million re-emigrants from the west (Eberhardt 2011). It was also noted that, notwithstanding processes of Germanisation, the lands in eastern Germany retained an autochthonous Polish population of some 2 million people.

A further document setting out the Polish case was a letter from Stanisław Grabski sent to the Soviet, British and American Delegations. This drew attention to the fact that, even following the establishment of a border along the Oder-Neisse Line: "Poland emerges from this War with a much reduced population size, since it cedes $180,000 \mathrm{~km}^{2}$ to the Soviet Union, along with the entire Ukrainian and Belarusian population inhabiting it up to 1939. Should it gain in exchange East Prussia, to the south and west of Konigsberg, as well as a western border along the Odra, with Szczecin, plus the Western Nysa, then Poland will lose around $80,000 \mathrm{~km}^{2}$ of its territory hitherto, with around 7 million of its people". 
At the end of his letter, Grabski stressed that it would not be just if Poland lost more than Germany as a result of the War, noting that: "If the ally of Poland, in accordance with the Crimea Resolution, repositions its eastern border to the line along which it ran at the end of the 14th century, it would probably not be unjust to push back the eastern border of the enemy-state, which is at the same time the western border of Poland, to a line that was likewise the border in that same 14th century. And that line was formed by the Oder with Szczecin and with the Lustian Neisse" (Bolewski 1977: 190-192).

Immediately after its arrival in Potsdam, the Polish Delegation engaged in several sessions of talks of a fundamental nature with Stalin, Churchill, Truman and their co-workers. The role of Head of Government Delegation was taken by Bierut, who referred back to Stalin and Molotov at regular intervals, presenting Poland's arguments to them. Both were then able to make use of them in subsequent discussions with Truman and Churchill (Musiał 2008: 128-158). A very important day was 24 July 1945, when the Polish delegation presented its postulates at the seventh sitting of the Ministers of Foreign Affairs of the Three Great Powers. On the same day, the Polish delegates were hosted by Churchill and Truman, while next day, Bierut sought to convince Churchill to express consent for the Oder-Neisse line to be used. This did not yield very positive effects, since Churchill was clearly opting for the Nysa Kłodzka. Hence at the outset Churchill was confusing what are known in Polish as the two Nysa rivers. Later on he came to appreciate the mistake he had made and made an official declaration to the effect that he had not given consent for the use of the Lusatian Neisse (or Western Neisse). The line of the Oder itself did not evoke any reservations among either the British or the American delegations. All that was required therefore was a more precise defining of where Szczecin/Stettin and Świnoujście/Swinemünde would be vis-à-vis the Polish-German border.

Appreciating the breakthrough nature of the situation following Churchill's veto, the
Polish delegation began on July 25 to consider a number of variant options. There was the least favourable of these, which Churchill had insisted on - i.e. the border at the Nysa Kłodzka/Glatzer Neisse, then further indirect variants involving the border along the River Bóbr/Bober and Kwisa/Queis, or else along the divides between them. It was considered that Churchill would ultimately agree to a border at the Kwisa, with there then being a possibility of a small shift west to the divide between the Kwisa and the Lusatian Neisse. Polish experts calculated that the variant with the border at the Nysa Kłodzka would see the country's acquisitions reduced by $18,780 \mathrm{~km}^{2}$, as compared with $3908 \mathrm{~km}^{2}$ were the border to be along the Kwisa. It should be stated here that, in the course of this argument, the Soviet delegation - up to and including Stalin himself - was entirely on the side of Poland and did what they could to prevail upon Churchill, and especially Truman, who regarded the whole issue with a degree of indifference (Kowalski \& Lippóczy 1971: 191).

Directly before the final decision on the border was taken, Churchill left the deliberations in Poznan in order to return to London so that he might be present as the results of the British General Election were made known. To the surprise of world opinion, and perhaps also to his own, Churchill's Conservatives did not prevail and he ceased to be Prime Minister. This of course meant that he did not return to Potsdam, with his place being taken by head of the Labour Party Clement Attlee. Needless to say, Attlee was almost entirely unprepared for the role that had unexpectedly come his way. He was not aware of the issues that had dominated previous discussions and could not therefore pull his full weight in negotiations involving Stalin and Molotov. Thus, despite the emergence of minor controversies, both the American and British Delegations offered their consent to the Neisse Line (i.e. that following the Lusatian Neisse).

It is hard to imagine if the situation would have looked different had Churchill won the 
election and returned to Potsdam. In his memoirs, however, he did write that he would not have consented to the Oder-Neisse Line (Cieślak et al. 1965: 535-536).

Lesser controversies were raised by matters of the future affiliation of the city of Szczecin, which is on the west bank of the Oder (Heitmann 2002). There was a need for agreement to be reached on the line of the border and to which country the Szczecin Lagoon was going to be assigned, as well as the water route linking Szczecin with the sea. The issue was considered by the last sitting of the Big Three on 1 August 1945. The version prepared for acceptance including the wording: "(...) the line of the border shall run to the Baltic Sea through Świnoujście".

Molotov proposed exchanging the word "through" with "to the west of", while Stalin went further and advocated the wording "directly to the west of". Both Prime Minister Attlee and President Truman gave their consent to this amendment.

A further question addressed concerned the delimitation of the Polish and Soviet parts of the old East Prussia. The Soviet version was adopted, whereby the border would be run to the north of Braniewo/Braumsberg and Gołdap/Goldap, by both the Polish and Soviet parties.

The final communique winding up the Potsdam Conference was drawn up on 2 August 1945 and ended with complete success for Poland. The Polish-German border was established along the Oder-Neisse Line, though Poland would also be granted the city of Szczecin, notwithstanding its location on the left bank of the Oder. The wording was as follows: "The Three Heads of Government agree that, pending the final determination of Poland's western frontier, the former German territories east of a line running from the Baltic Sea immediately west of Swinemünde, and thence along the Oder River to the confluence of the Western Neisse River and along the Western Neisse to the Czechoslovak frontier, including that portion of East Prussia not placed under the administration of the Union of Soviet Socialist Republics in accordance with the understanding reached at this Conference and including the area of the former free city of Danzig, shall be under the administration of the Polish State and for such purposes should not be considered as part of the Soviet Zone of Occupation in Germany" (RIIA 1946: 203).

Every sentence, and even every word, of this vitally important wording that decided on the course of the Polish-German border was studied and commented upon in various ways by Polish and German lawyers, as well as those in the 'Anglo-Saxon' world. There is an extensive subject literature on this, which is now of nothing more than historical significance (Goguel \& Pohl 1956; Rhode \& Wagner 1959; Klafkowski 1970; Skubiszewski 1975; Domke \& Domke 2008). The irrevocable nature of what was agreed at Potsdam was next attested to by the transfer of the German population out of the newly-Polish areas. Chapter 13 of the Potsdam Agreement contained the following provisions: "The Three Governments, having considered the question in all its aspects, recognize that the transfer to Germany of German populations, or elements thereof, remaining in Poland, Czechoslovakia and Hungary, will have to be undertaken. They agree that any transfers that take place should be effected in an orderly and humane manner".

To ensure the implementation of this decision at a later date, since it was only on 20 November 1945 that it was adopted by the Allied Control Council, a programme by which expulsions might be achieved in line with established guidelines was to commence in December 1945 and to end in July 1946. In fact, however, they began earlier and persisted for much longer.

\section{Issues of delimitation}

The delineation of the Polish-German border along the Neisse and Oder did not present too many difficulties. The right bank was to belong to Poland, the left to the then Soviet Zone of Occupation within Germany. The border was supposed to follow the middle of the 
river channel, so this did not pose a problem. Things were different with the identification of the border passing west of Szczecin - from the Oder via the Szczecin Lagoon or Gulf of Stettin, up as far as the shoreline of the Baltic Sea. A Polish-Soviet Commission was founded to set the course of the border in the field. On the Polish side, the first Polish President of Szczecin, Piotr Zaremba, was among those who participated, and he made persistent efforts to ensure that the line followed by the border would be more suitable for Poland (Fig. 5).
Subsequent minor modifications only involved short sections of border. Once the border had been confirmed in 1945, Świnoujście lost its access to drinking water - a circumstance that required exchanges of borderland areas by the two sides. A problem proving harder to resolve concerned the delimitation of territorial waters of Poland on the one hand and the GDR on the other - all the more so since the navigable route passed via a shelf belonging to East Germany. The controversy surrounding this issue in fact persisted for several decades. But these were
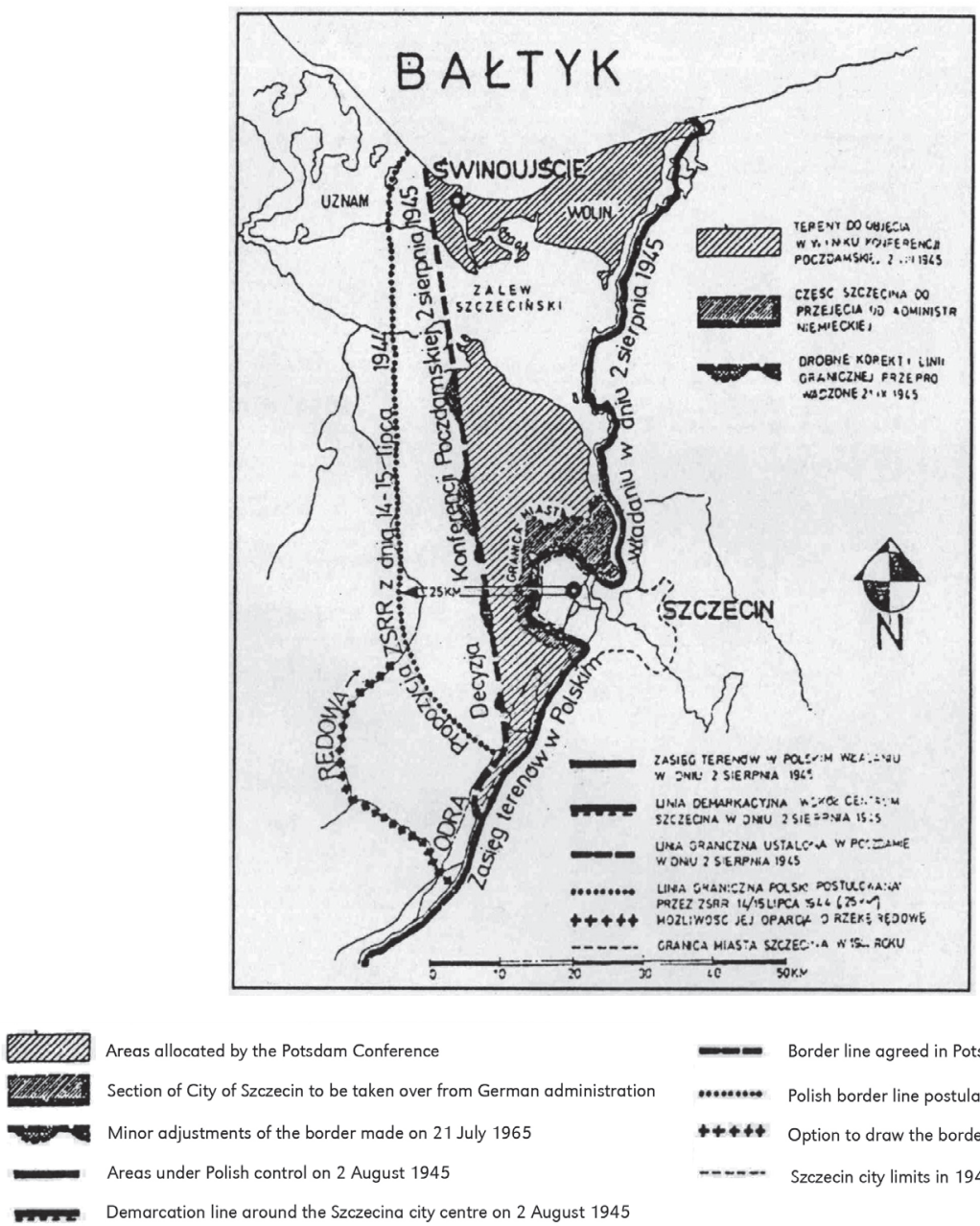

Areas allocated by the Potsdam Conference

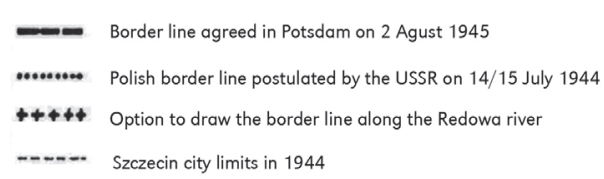

Figure 5. Concepts for change in the course of Poland's western border in the vicinity of Szczecin in 1945 Source: Zaremba 1986: 230. 
in fact secondary matters of local significance compared to what was agreed at the Potsdam Conference, to establish a new border along the Oder-Neisse Line. This imposed verdict was in fact very hard to accept for German society. Provinces like Silesia, Pomerania or East Prussia were not deemed somehow marginal, but were in fact viewed by Germans as core German areas, whose loss would prove hard to get over. Indeed, for many years, the post-War borders were regarded by most Germans as of a temporary nature, and so punitive that eventually they would need to be modified (Sułek 1969; Dobrzycki 1975; Marczak 1995). A return to the pre-War situation was thought about and hoped for, or at least some kind of compromise solutions that would allow some of the lost lands to go back to Germany. However, as time passed, it became more and more obvious that such ideas were illusions. Indeed, amongst the elite of Germany there was an ever more fixed and widespread conviction regarding the irrevocable loss of what had once been Germany's eastern provinces.

The first formal legal interstate act confirming the existing course of the border along the Oder and Neisse was the Zgorzelec Agreement of 6 July 1950 concluded between the People's Republic of Poland and the German Democratic Republic. However, further steps towards international recognition encountered numerous difficulties in the Federal Republic of Germany, on account of this country's determination to maintain the constitutional position regarding the existence of Germany within its pre-War borders. In contrast, these were all matters of little import for the Western states, given the magnitude of the Cold War, and the way in which that absolutely disfavoured any kind of treatymaking. Indeed, even the Peace Conference that had been foreseen for the near future at Potsdam never actually saw the light of day.

The real geopolitical border at this point was anyway the one at the Elbe, which divided two German states now belonging to opposing political, military and economic camps. Ultimately, the ratification of a border agreement between Poland and the reunified
Germany had to wait fifty years following the end of the War (and indeed for two years after the Berlin Wall came down). A this point there came the long-awaited and definitive recognition by Germany (during the sitting of the Bundestag of 16 December 1991) that the Polish-German border ran along the Oder-Neisse Line. The German Parliament would go on to confer force of law upon its decision a month later, on 16 January 1992.

\section{Summary}

The establishing of Poland's western border along the Oder-Neisse Line was a milestone event in the thousand-year history of the Polish state and nation, since it was associated with the incorporation into Poland of Lower and Upper Silesia, East Brandenburg, Western Pomerania, the city of Gdańsk and the southern part of East Prussia. This was therefore a return to the lands that were the cradle of the Polish nation just as statehood was beginning to develop. Notwithstanding the major net loss of territory this entailed, the overall balance between what had been lost and what gained was a favourable one for Poland, since the provinces added to the country were well-managed, furnished with a technical infrastructure that was both rich and dense, and characterised by the presence of both a werll-developed network of towns and cities and relatively up-to-date agriculture.

After the War, neither the Polish nation nor its patriotic elite were fully aware of the revolutionary and overwhelmingly positive transformation of the border situation that had taken place thanks to what was decided at Potsdam. The then political situation was seen in terms of limitations on sovereignty, satellite status, the loss of the Eastern Lands and the devastation of Warsaw. These were all indisputable facts, but they had little to say about the more distant future. Indeed, both geopolitical/territorial and economic and social matters were very much overlooked. No note was taken of the fact that Poland within its 1939 borders was and would forever have been condemned 
to instability and short-termism in outlook. Longer-term chances of persistence were always going to be in doubt where Upper Silesia was divided, East Prussia and the Free City of Danzig remained in existence and the question of Ukraine remained unresolved.

It is not correct to extend equivalent treatment to the consequences of Yalta and Potsdam. The verdict from both was an acceptance of the fact that Poland would come within the Soviet orbit, but there was quite different consideration given to the territorial issues. Yalta brought an irrevocable decision that Poland's Eastern Lands would be lost to the USSR, but the provisions as regards compensation in the west were only couched in the most general terms, with nothing binding agreed upon. The Oder was indeed indicated, but in a general way (and prior to World War II the Polish border had also reached the Oder near Raciborz (Ratibor). The most realistic scenario was one in which Poland would regain the southern part of East Prussia, the Free City of Danzig and part of the Opole region. In total this would be an area reaching around $30,000 \mathrm{~km}^{2}$. In contrast, the provisions arising out of the Potsdam Conference would assign more than $100,000 \mathrm{~km}^{2}$ to Poland, with the package including such great cities as Wrocław, and Szczecin plus Świnoujście. Thanks to the setting of the border at the Lusatian Neisse and not the Nysa Kłodzka (Eastern Neisse), Poland also gained Legnica/ Liegnitz, Wałbrzych/Waldenburg, The Kłodzko/Glatz and Jelenia Góra/Hirschberg Basins, and Zielona Góra/Grünberg plus Żary/Sorau and Żagań/Sagan.

What had thus appeared on the map of Europe was a Polish state with entirely changed political boundaries. This was documented in a 1946 map by Maria Kiełczewska memorably entitled Polska wczoraj i dziś (Poland yesterday and today) (Fig. 6) (Kiełczewska-Zaleska 1946).

Leading Polish geographer Eugeniusz Romer used the circumstances of a 1945 study to point out the weighty if positive consequences of Poland's shift from 'the East' to 'the West'. He felt that Poland would thus be afforded civilisational and spiritual progress, and regarded the associated events as amongst the most important in the whole history of the Polish nation, opening up a new millennium in Poland's history (Romer 1945).

The Potsdam decision sanctioning and indeed requiring the resettlement of the German population had major consequences for demography and ethnicity alike. Once the Germans had moved out, the formerly German areas received an influx of people of Polish nationality but disparate territorial origin. While only $70 \%$ of the people in preWar Poland had actually been Poles (with Ukrainian or Belarusian nationality prevailing over extensive areas in the east), the border changes and effective westward shift of the new Poland combined with resettlement en masse to generate a state that was uniform in terms of nationality and religious affiliation, and thus unthreatened by any tendencies towards disintegration or centrifugal change (Eberhardt 2003).

If one leaves aside their unbending and at times inhumane face, the Potsdam decisions regarding the expulsion of Germans did bring about increased homogeneity as regards nationality (Eberhardt 2011). An effective stop was also put to any possible inclinations towards revisionism or revenge. The borderland in fact became safe and not prone to either ethnic conflict or nationalistic propaganda.

The establishment of the border along the Oder-Neisse line actually had serious geopolitical consequences for Central and Eastern Europe as a whole. Poland's regaining of a Baltic shore running between Krynica Morska/Neukrug and Świnoujście/ Swinemünde changed the country's position vis-à-vis Germany, at a stroke reconfiguring the geostrategic system of the southern Baltic basin. Up until the outbreak of World War I, the whole southern shore of the Baltic as far as Klaipeda/Memel had been German. Post-1919 Poland gained limited access to the sea, but was still very much cut off from it, with the Pomeranian 'Corridor' itself representing a source of Polish-German conflict. 
There was a similar change of configuration in the foothills region of the Sudety Mountains. German Lower Silesia with the Opole region and the western part of Upper Silesia separated Poland from the Czech Lands. But this further territorial wedge extending far to the east and inhabited by Germans was polonised and hence removed entirely. And not far from Warsaw there had been East Prussia, limiting the Polish lands from the north. This was also annihilated. In all these ways Poland had achieved a kind of success. However, while the border was shifted $100 \mathrm{~km}$ to the north, there remained Kaliningrad District, belonging to the Soviet (and Russian) Empires and representing a potential geopolitical threat.

The facts presented here attest to the major consequences of the Potsdam Conference, which led to the emergence of a compact

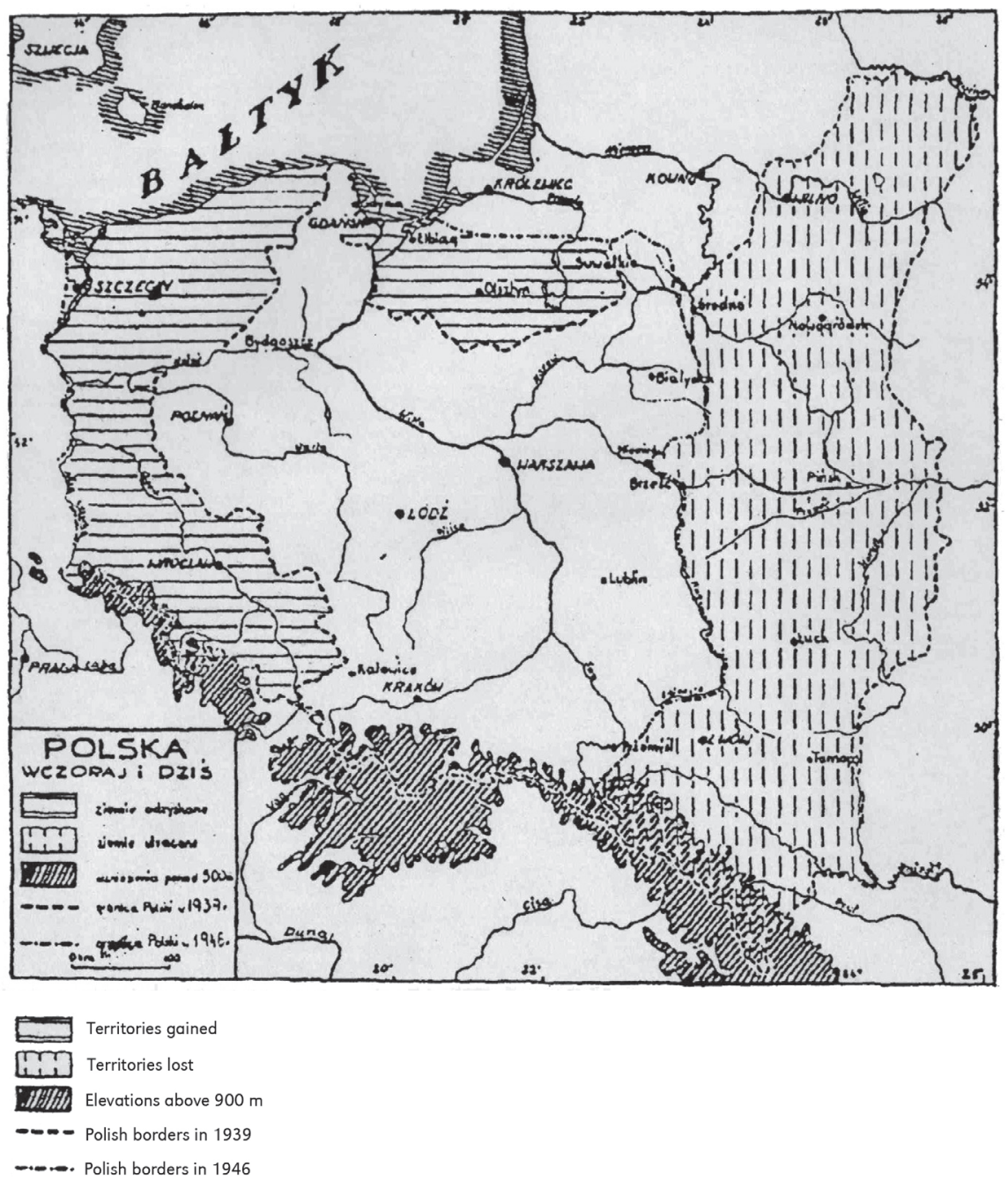

Figure 6. "Poland yesterday and today" Source: Kiełczewska-Zaleska 1946. 
Polish state in the basins of the Vistula and Odra, occupying a large part of the Central European Lowland between the Carpathians and the Baltic Sea.

\section{References}

Alekseev I.P. (ed.), 1914. Karta budushchei Evropy. Moscow: Izd. I. Alekseeva.

BAszKIEWICZ I., 1954. Powstanie zjednoczonego państwa polskiego na przełomie XIII i XIV wieku. Studia nad Historiq Państwa i Prawa, ser. 2, vol. 1, Warszawa: Książka i Wiedza.

BDGG, 1985. Jalta - Potsdam und die Dokumente zur Zerstörung Europa. Beihefte zu Deutschland in Geschichte und Gegenwart, 13, Tübingen: Grabert Verlag.

Betza S., 1902. My czy oni na Szląsku Polskim? Warszawa: Gebethner i Wolff.

BieRZANEK R., KuKUtKA J. (eds.), 1965. Dokumenty i materiaty na Konferencji Pokojowej w Paryżu w 1919 r. Dokumenty i materiały. Vol. 1, Warszawa: Państwowe Wydawnictwo Naukowe, Polski Instytut Spraw Międzynarodowych.

Bolewski A., 1977. Z drogi do Poczdamu. Kraków: Wydawnictwo Literackie.

Butler R., Pelly M.E., Yasamee H.J., (eds.), 1984. Documents on British policy overseas. Ser. 1, vol. 1, The Conference at Potsdam. July-August 1945, London: Her Majesty's Stationery Office.

ChURCHILL W.S., 1950. The grand alliance. Vol. 3, Second World War, London: Cassel.

ChurChill W.S., 1954a. The hinge of fate. Vol. 4, The Second World War, London: Cassel.

ChurChill W.S., 1954b. Triumph and tragedy. Vol. 6, Second World War, London: Cassel.

Cieślak T., Stanistawska S., ZabietŁo S., KowalSKI W. T., JURKIEWICZ J., 1965. Sprawa polska w czasie drugiej wojny światowej na arenie międzynarodowej. Zbiór dokumentów. Warszawa: Polski Instytut Spraw Międzynarodowych, Państwowe Wydawnictwo Naukowe.

Consulibus aka Wakar W., 1926. Doświadczenia i błędy naszej polityki zagranicznej wobec zadań chwili. Warszawa: Nakładem Biura Społeczno Literackiego.
Editors' note:

Unless otherwise stated, the sources of tables and fugures are the authors' on the basis of their own research.

DeBra J.A., 2003. The Oder-Neisse line. The United States, Poland and Germany in the cold War. Westport: Praeger.

DMowski R., 1908. Niemcy, Rosya i kwestya polska. Lwów: Towarzystwo Wydawnicze.

Domke S., Domke R., 2008. Podstawy polskiej granicy zachodniej w układach poczdamskich. Geopolityka: Biuletyn Naukowo-Analityczny Instytutu Geopolityki, 1, pp. 114-123.

DYNARSKI M., 1997. Ziemie postulowane (ziemie nowe) $w$ prognozach $i$ działaniach polskiego ruchu oporu 1939-1945. Wrocław: Wydawnictwo Uniwersytetu Wrocławiego.

DYNARSKI M., Derwiński Z., 1990. O Odrę, Nysę Łużycka i Bałtyk (1939-1944). Wrocław-Warszawa: Uniwersytet Wrocławski.

EberHARDT P., 2003. Ethnic groups and population changes in twentieth-century. Central-Eastern Europe. History, data and analysis. New York: M.E. Sharpe.

Eberhardt P., 2011. Political migrations on Polish territories (1939-1950). Monografie IGiPZ PAN, 12, Warszawa: Instytut Geografii i Przestrzennego Zagospodarowania PAN.

EBERHARDT P., 2012. The Curzon Line as the eastern boundary of Poland: The origins and the political background. Geographia Polonica, vol. 85, no. 1, pp. 5-21.

Fels H., 1960. Between war and peace. The Potsdam Conference. Princeton: Princeton University Press.

Gluck L., 1971. Od Ziem Postulowanych do Ziem Odzyskanych. Warszawa: Instytut Wydawniczy PAX.

Goguel R., Pohl H., 1956. Oder-Neisse. Berlin: Eine dokumentation Kongrs-Verl.

Hartenstein M.A., 2006. Die Geschichte der Oder-Neisse Linie. München: Olzog Verlag.

Heitmann C., 2002. Die Stettin-Frage. Die KPD, die Sowjetunion und die deutsch-polnische Grenze 1945. Zeitschrift für Ostmitteleuropa Forschung, vol. 51, no. 1, pp. 25-63. 
KARSKI J., 1998. Wielkie mocarstwa wobec Polski 1919-1945: Od Wersalu do Jałty. Lublin: Wydawnictwo Uniwersytetu im. M. Curie-Skłodowskiej.

KeRSTEN K., 1989. Jalta w polskiej perspektywie. Warszawa: Niezależna Oficyna Wydawnicza.

KęRZYŃSKI W., 1882. O ludności polskiej w Prusiech niegdyś Krzyżackich. Lwów: Zakład Narodowy im. Ossolińskich.

KietCZewsKa-Zaleska M., 1946. O podstawy geograficzne Polski. Poznań: Instytut Zachodni.

KietcZewska-Zaleska M., Gluck L., KacZmarczyK Z., WOJCIECHOWskI Z., 1946. O lewy brzeg Odry. Prace Instytutu Zachodniego, 5, Poznań: Wydawnictwo Instytutu Zachodniego.

KLAFKOWSKI A., 1970. Granica polsko-niemiecka po II Wojnie Światowej. Poznań: Wydawnictwo Poznańskie.

Kochanowski J., Kosmala B., 2013. Deutschland, Polen und der Zweite Weltkrieg: Geschichte und Erinnerung. Potsdam-Warszawa: Deutsch-Polnisches Jugendwerks.

Kокот J., 1957. Logika Poczdamu. Katowice: Wydawnictwo Śląsk.

KoWALSKI W.T., LIPPóczY P., 1971. Granica na Odrze i Nysie Łużyckiej: Zbiór materiałów i dokumentów. Vol. 1, Warszawa: Polski Instytut Spraw Międzynarodowych.

KRÜLlE S., 1970. Die Völkerrechtlichen Aspekte der Oder-Neisse Problems. Berlin: Duncker \& Humblot.

LABUDA G., 1974. Polska granica zachodnia: Tysiac lat dziejów politycznych. Poznań: Wydawnictwo Poznańskie.

ŁAHODA M., 1918. Zachodnia granica Polski. Warszawa: Komitet Obrony Narodowej.

Modrzew aka Prorok L., 1944. Dziedzictwo Piastów. Rzecz o polskiej granicy zachodniej. Warszawa: Narodowy Instytut Wydawniczy.

Morgenthau H., 1945. Germany is our problem. New York-London: Harper \& Bros.

MroczKo M., 1986. Polska myśl zachodnia 19181939. Dzieje polskiej granicy zachodniej, 6, Poznań: Instytut Zachodni.

Musiat B., 2008. „Niechaj Niemcy się przesunq". Stalin, Niemcy i przesunięcie granic Polski na zachód. Arcana, 79 (1), pp. 128-158.

Neyman L., 1941. Polska po wojnie. Warszawa: Szaniec.

Neyman L., 1941. Szaniec Bolesławów. Warszawa: Szaniec.
OrzeCHOWski M., 1969. Odra - Nysy Łużycka Bałtyk w polskiej myśli politycznej okresu drugiej wojny światowej. Wrocław: Zakład Narodowy im. Ossolińskich.

PAJEWSKI J., 1963. Problem polsko-niemiecki w traktacie wersalskim. Poznań: Instytut Zachodni.

PLOKHY S.M., 2010. Yalta 1945. The price of peace. New York: Viking.

Rhode G., Wagner W., 1956. Quellen zur Entstehung der Oder-Neisse-Linie in den diplomatischen Verhandlungen während des Zweiten Weltkrieges. Deutschen Ostgebiete, 3, Stuttgart: Brentano Verlag.

RIIA, 1946. United Nations Documents 1941-1945. London: Royal Institute of International Affairs.

Romer E., 1945. Duch Polski Zachodniej. Kraków: Polski Zwiq̨zek Zachodni.

Roock R.C., 1990. Stalin fixes the Oder Neisse Line. Journal of Contemporary History, vol. 25, no. 4, pp. 467-488.

RysIAK G. (ed.), 1970. Zachodnia granica Polski na konferencji w Poczdamie: Zbiór dokumentów. Biuletyn Niemcoznawczy, no. 4-5 (28-29), Opole: Instytut Śląski.

SANSBURY K., 1996. Churchill and Roosevelt at war: The war they fought and the peace they hoped to make. London: Macmillan.

SkUBISZEWSKI K., 1975. Zachodnia granica Polski w świetle traktatów. Studium Niemcoznawcze Instytutu Zachodniego, 26, Poznań: Instytut Zachodni.

SUŁOWSKI Z., 1952. Najstarsza granica zachodnia Polski. Przeglą Zachodni, 3-4, Poznań: Instytut Zachodni, pp. 343-383.

Thum G., 2011. Uprooted: How Breslau became Wrocław during the Century of expulxions. Princeton: Princeton University Press.

Timmermann H. (ed.), 1997. Potsdam 1945: Koncept, Taktik, Irrtum? Berlin: Duncker\&Humblot.

UMIASTOWSKI R., 1921. Terytorium Polski pod względem wojskowym. Part 1, Warszawa: Książka.

USDS, 1945. The Conference of Berlin, 1945. Vol. 1, United States Department of State, Washington, DC: Government Printing Office, pp. 1509.

USDS, 1955. Foreign relations of the United States. Diplomatic Papers. The Conferences at Malta and Yalta 1945. United States Department of States, Washington, DC: Government Printing Office. 
Wagner W., 1968. Die Entstehung der Oder-Neisse-Linie in den diplomatischen Verhandlungen während des Zweiten Weltkrieges. Marburg (Lahn): J.G. Herder Institut.

WaPIŃSKI R., 1994. Polska i małe ojczyzny Polaków: Z dziejów kształtowania się świadomości narodowej w XIX i XX wieku po wybuch II Wojny Światowej. Wrocław-Warszawa-Kraków: Zakład Narodowy im. Ossolińskich.

WojCIECHOWSKI Z., 1945. Polska-Niemcy: Dziesięć wieków zmagania. Prace Instytutu Zachodniego, 3, Poznań: Instytut Zachodni.
Zabiegto S. (ed.), 1958. Sprawa polska podczas II Wojny Światowej w świetle pamiętników. Warszawa: Polski Instytut Spraw Międzynarodowych.

Zaremba P., 1986. Walka o polski Szczecin. Wrocław-Warszawa-Kraków-Gdańsk-Łódź: Zakład Narodowy im. Ossolińskich.

ZIELINSSKI H., 1964. Polska myśl polityczna a sprawa ziem zachodnich (przed 1914). Śląski Kwartalnik Historyczny Sobótka, vol. 19, no. 1-2, pp. 143-159. 
http://rcin.org.pl 